\title{
Young Indonesian Cruise Workers, Symbolic Violence and International Class Relations
}

\author{
Luh Putu Artini \\ English Department, Ganesha University of Education \\ Jl. Udayana, Singaraja, Bali, 81116, Indonesia \\ Tel: 62-36-222-570 E-mail: tien_miasa@hotmail.com \\ Pam Nilan (Corresponding author) \\ School of Humanities and Social Science, The University of Newcastle \\ University Drive, Callaghan, 2308 NSW, Australia \\ Tel: 61-2-4921-5912Ｅ-mail: Pamela.Nilan@newcastle.edu.au \\ Steven Threadgold \\ School of Humanities and Social Science, The University of Newcastle \\ University Drive, Callaghan, 2308 NSW, Australia \\ Tel: 61-2-4921-6904Ｅ-mail: Steven.Threadgold@newcastle.edu.au
}

Received: December 15, 2010 Accepted: January 13, 2011 doi:10.5539/ass.v7n6p3

\begin{abstract}
This article reports on an investigation of the experiences of well-educated young Indonesians who choose a career in cruise ship work rather than go to university, or work in the local tourist industry. A sociological approach is taken that sees the cruise ship environment as a microcosm of international class relations. Attention is paid to the symbolic violence experienced by young workers who find their dream of travel on the high seas consists of mundane service work in uncomfortable conditions far from home. The phenomenon suggests the emergence of a young cosmopolitan migrant worker who does not experience any acculturation to a new country, but acculturation to life in a "total environment" of 24 hour service work subject to few international labor regulations. Undoubtedly there are financial and work experience benefits, but there is also much to be endured in the extended transition from youth to adulthood during cruise ship work.
\end{abstract}

Keywords: Cruise ship work, Indonesia, Youth transitions, Symbolic violence, International class relations

\section{Introduction}

\subsection{Young Southeast Asian Cruise Ship Workers}

We give an account here of preliminary research on well-educated young Indonesians who sign up for international cruise ship training and work. Much of the data was collected in Bali. Cruise ship work is an increasingly popular career choice for senior high school graduates on the Hindu-majority island of Bali, where the main industry is tourism. Although there might appear to be little difference between service work in the local tourism industry and cruise ship work as career choices, the two forms of work show some striking differences.

We propose that the transnational cruise ship industry is a microcosm of the globalized labour force. High-level, well-paid crewmembers are from western countries, while low-level service workers are most often young Southeast Asians, especially from the Philippines, but also from Indonesia (Seal, 1998; Wood, 2002). In Indonesia, Bali has swiftly become a key recruitment site because the English language proficiency of high school graduates is impressive, and religious tolerance is high. Wood (2002, p. 420) claims that no industry 
constitutes a more extreme case of globalization than the cruise industry, "due to its highly mobile nature and its unique liberation from traditional constraints of place". New types of stratified global interconnections are forged in these enormous floating hotels, bringing together low-level service workers from Southeast Asia, management staff from developed countries, and older - primarily western - tourists who want a sense of luxury in affordable cruising. There is a rigid hierarchy on board ship that mirrors contemporary class relations networked across the world. The tourism promise made by cruise operators is for "unrivalled" personal service, with room boys, masseurs and other service staff on call 24 hours a day. While this might seem similar to the service offered in luxury hotels, it is a very different experience for staff. They are at sea, far from home, for very long periods, in the "total environment" of the ocean liner, where few labor regulations apply. Idealistic young Southeast Asian cruise ship workers find that the reality does not match their dreams.

\subsection{A New Form of Transnational Class Relations}

In one sense young cruise ship workers might appear to exemplify the new paradigm of cosmopolitanism well-educated, open to the world, moving frequently in transnational space (Beck, 2002). Yet in another sense they do not match the paradigm because their geographical mobility is not privileged by wealth (Calhoun, 2002) nor by completely free choice. Complex migratory work patterns and new forms of international class relations are evident in this phenomenon, so it is appropriate to look at class and symbolic violence (see Threadgold, in press) for understanding the experience of young Southeast Asian cruise ship workers. The idea of class relations mapped across a global occupational division of labor favors the notion of class advanced by Bourdieu (1987), rather than Marxist theorists, because it looks beyond a system of positions defined relative to ownership/control over the means of production. For Bourdieu, class boundaries become established through social practices articulated in relation to the operation of economic and cultural capital. Social actors "take on" and embody the attributes and values of the class with which they are associated as a collective. Bourdieu called this physical and cultural internalization of class position - "habitus"; a set of generative dispositions through which the individual habitually apprehends and reacts to, the surrounding environment, according to his or her class location. In cruise ship service work, young Indonesians must modify middle-class habitus to match the demeanor of the colonial domestic servant.

It can be argued that a form of symbolic violence (Bourdieu, 1982) takes place when well-educated, middle-class Southeast Asian youth take jobs as low-level service workers on budget holiday cruise ships, where they must smilingly meet the constant demands of working class western tourists. The young workers have to show a suitably subservient demeanor, modeling the deferential attitude of the colonial servant from a bygone era. Some programs encourage trainees to "never say no" to a passenger request. Paradoxically, many Balinese trainees would have grown up with a servant at home, since a live-in maid is nearly always employed for urban Indonesian households in the "intermediate class" (White, 2006). Now they must become docile servants themselves. Bourdieu maintained that symbolic violence is exercised upon a social agent with his or her complicity, "the specificity of symbolic violence resides precisely in the fact that it requires of the person who undergoes it an attitude which defies the ordinary alternative between freedom and constraint" (Bourdieu, 1982, p. 36). This describes very well the situation of young Southeast Asian cruise ship workers. They are certainly "free" to initially choose this line of work, but once at sea, they are "constrained" from refusing a tourist request, or leaving the position. When the cruise finishes they can refuse to pursue the contract, but may well be compelled to go to sea again by the pressure of training and recruitment debts, and family dependence back home.

Cruise ship service work entails a more powerful modification of habitus for a young person than that of the local service worker in a tourist resort in Southeast Asia who visits the family every couple of days or weeks. The ship is a "total environment" (Goffman, 1961; Weaver, 2005) in which there are few if any personal historical points of reference during a six or nine month contract. In Asylums, Goffman (1961) describes various "mortifications of the self" that occur in total institutions which have the effect of reconstructing the person to an extent which would not occur in more open, diverse or comfortable social contexts. This happens partly through the social actors adopting "ascribed" attributes or capacities. Some of the attributes ascribed to young Balinese cruise ship workers are docility, deference, politeness, affability and endurance. On a cruise ship there is literally no escape from long shifts and cramped conditions, nor from humiliation, exploitation or harassment should it occur. Young workers labor in a harsh working environment with no external vigilance over the enforcement of safety, or benchmarked industrial regulations. Young workers cannot leave an intolerable, or even dangerous, work situation until the next port, where they are likely to be stranded far from home and penniless. Internet and mobile phone access for crew members is limited and not reliable far from land. Sadly, the reward of wages and 
tips is rarely as much as they hoped for in high school dreams. This is a very different model of school to work transition.

\subsection{Youth Transitions}

British youth researchers Furlong and Cartmel $(2006$, p. 9) maintain that in the past there were three kinds of sequential youth transitions to adulthood: "school to work transitions, domestic transitions and housing transitions". The young person completed his or her education, found a job, started to live independently, found a marriage partner, and moved into his or her own home to start a family. This model has guided much previous western inter-disciplinary research on youth (Cieslik \& Pollock, 2002). Yet in the new century Skelton (2002) maintains it does not fit well with the conditions of late modernity even in western countries. Due to significant changes in the nature of work, young people's transition experiences may show increasing uncertainty and fragmentation (Threadgold \& Nilan, 2009), expressed in "increasingly prolonged, decoupled transitions between education and work, dating and mating, and childhood and adulthood" (Côté, 2003, p. 2). Some claim this is "arrested adulthood" (Côté, 2000).

To evaluate whether this holds true for contemporary youth transitions in developing countries, specific investigations are required. Youth researchers working outside western countries such as Fokwang (2008) claim that "arrested adulthood" does effectively describe the blocked situation of African young people who are unmarried and uncertain of their future due to job insecurity. Other studies give a more complex picture. Roberts et al. (2009) studied youth transitions in the South Caucasus to find a normative family formation sequence structurally reinforced by early marriage conventions, limited housing options and the necessity for households to maintain multiple income streams. Similarly, in Muslim-majority Indonesia some traditional patterns of youth transitions are retained, even while extended education and work mobility (Sziraczki \& Reerink, 2004), as a well as late marriage (Nilan, 2008), postpone the achievement of adulthood. To adequately describe the education-to-work transition of well-educated Indonesian youth to work on cruise ships, we must look at "push" and "pull" factors rather than the limited notion of "arrested adulthood". Since the individual is much less emphasized in Southeast Asian countries, the matter of choice needs to be seen as collective consensus in which families play a role.

\subsection{Push and Pull Factors}

Indonesia is a "normal middle-income country" (Anderson, 2007, p. 6) with a relatively young and increasingly urbanized population. Over 28 per cent of the population of 242968342 million is under 15 . More than 86 per cent of the population is Muslim (UNDP, 2008, p. 245), except for Bali, which has a Hindu majority. Youth unemployment in Indonesia is high, with many high school graduates and even university graduates looking for work in the cities. In Indonesia it is claimed, "the higher one's education the smaller the chance one will get a job" (Jardine, 2008, p. 3). Headlines like this feature in the Indonesian media in June each year, and undoubtedly affect the post-senior high school choices of some young Indonesians and their families. So it is no surprise that cruise ship work seems appealing. Young people are drawn to the idea of travel and earning high wages. In Bali it appears around two thirds of applicants are male, although the growth in spa services and elaborate beauty treatments now favors recruitment of young women as well.

\section{The Cruise Ship Industry}

\subsection{Cruise Ships}

International institutions, and even sovereign nations themselves, are almost powerless "in regulating what goes on in both national and international waters" (Wood, 2002, p. 421) on board ships. Accordingly, cruise ship crews "are subject neither to the labor laws of their countries of origin nor to those of the country of their employer; rather, their contracts specifically state that they are subject to the laws of the country in which the ship is tagged" (Wood, 2000, p. 351), that is, flying a flag of convenience. "Flags of Convenience" are open registries where ship owners are able to transfer the responsibility for overseeing their compliance with local and international regulations to "flag states", most often those with a lax attitude to the enforcement of compliance. Panama, Liberia and the Bahamas are responsible for regulating around half of the global cruise ship fleet.

We can therefore describe the cruise ship industry as an operating environment with few restraints, where both labor and capital move freely to the optimization of profit: "vessels can be built in one country, owned by those living in another, registered and flagged in a third country, possibly managed by a company in a fourth country and crewed by seafarers from all over the world" (Chin, 2008, p. 9). The regulation of labor, wages and conditions for cruise ship workers is consequently a fragmented process with many lucrative loopholes for ship owners. The industry is dominated by three transnational corporations (with many subsidiaries): Carnival 
Corporation, Royal Caribbean Cruise lines and Star Cruises. Cruising is a multi-million dollar competitive industry, and growing all the time. For maximum profits, labor costs must be kept low so that costs to consumers still fall within the reach of ordinary holiday-makers in the developed countries of the world. It is no surprise that cruise lines recruit the well-educated, polite and well-behaved sons and daughters of the middle class in selected Southeast Asian countries, and pay them wages which might seem high at home but don't go far in the end.

Cruise ships make huge profits because they run at a capacity of more than 90 per cent, far higher than land-based hotels (Wilkinson, 1999, p. 262). Many luxury cruise lines boast in advertising that there are 1-2 crew members for each passenger. It seems each pair of passengers will have something like a personal servant on board, but in fact a third of the crew are not in direct service roles. Young workers employed behind the scenes in kitchen work, or similar, earn a salary of around USD $\$ 350$ per week, with no tips. Waiters, busboys/assistant waiters, bar waiters/waitresses, bartenders and so on, earn a small base salary. They earn tips, and income can reach US\$2 500 per month. Once signed, the young worker must pay travel expenses to the port of departure. Most cruise lines demand employees buy a one-way ticket and pay a travel deposit to be returned for buying a ticket home when the contract finishes. If he or she is fired or leaves the job, the deposit is forfeited. Once on board the young recruit will work shifts of around fourteen hours, will work seven days a week, and live in a crowded, windowless cabin (Cruiseshipjobs, 2010).

\subsection{Recruitment}

The ideal Southeast Asian employee is a young man or woman with good grades, of average height and pleasing appearance, good manners, confident, and speaks English well (Cruiseshipjobs, 2010). He or she should not be too religious and be willing to do whatever is asked. Targeting for training begins even before graduation from senior secondary school in Bali. Eager applicants compete to enter a training college as soon as final examination results become available. High tuition fees relative to an average family income must be paid. This indicates that the family of the ideal new recruit is probably middle class, from what is sometimes described as the "intermediate class" (White, 2006) in Indonesia, characterized by upward mobility aspirations. Families may have to borrow substantially against the future salary of their young cruise ship worker to pay for training and travel costs.

\subsection{Passengers}

To grasp the magnitude of the gap between low-level service workers and the guests they serve, it is worth giving an approximation of the passenger experience to be found on popular large cruise ships. A good example is leading cruise operator Mediterranean Shipping Company (MSC), based in Geneva. MSC's new ship Magnifica, carrying 2500 passengers, was launched to a fanfare of hyperbole in 2010:

Lucky guests on MSC Magnifica are expertly looked after by a 1,000-strong crew, enjoying the best of modern Italian style. At the heart of MSC Magnifica is a lush haven of tranquillity, the luxurious MSC Aurea Spa. This sumptuous wellness centre offers a myriad of relaxation options from saunas and Turkish baths to a fitness centre, beauty salon, Thalassotherapy room, relaxation area and massage rooms. Why not give in to the magic of an authentic Balinese massage from professional masseurs? (...) MSC Magnifica boasts all the fine dining and entertainment amenities you would expect on a superior luxury liner, and much more besides. With a choice of 5 restaurants, numerous bars, an internet café and cigar lounge - not forgetting the plush 1200 -seat theatre, cinema, casino and disco - the MSC Magnifica truly lives up to her Italian name - magnificent! (MSC cruises, 2010).

This collection of enchanted superlatives matches George Ritzer's (1999, pp. 8-9) description of cruise ships as "cathedrals of consumption" that disguise highly rationalized and stylized procedures operating to give a sense of luxury and privilege. It is mentioned that the spa offers "an authentic Balinese massage from professional masseurs". This is one reason why Bali has become a key site of cruise ship recruitment in Indonesia. Local colleges offer specialized spa training to young Balinese women.

The kind of advertising demonstrated above appeals to western honeymoon couples and older working class couples. The cruise promises the opportunity to savor the pleasures of upper middle-class life in a controlled and limited travel environment. We can estimate the socio-economic status of such couples in Australia by looking at costs. In July 2010, MSC Cruises Australia offered a twin-share deal on MSC Splendida for 22 nights winter cruising in the Mediterranean for $\mathrm{A} \$ 2048$ per person. The airfare was quoted as $\mathrm{A} \$ 2056$ from Sydney to Milan return. That makes $\mathrm{A} \$ 4104$ per person for the cruise holiday, placing it within reach of many Australian honeymooners and retirees. From these figures we can judge the difference between passenger prices and service worker wages. 


\section{Methodology}

\subsection{Gathering Data}

This article reports on data from a small case study conducted by the authors in 2010. 17 Balinese informants were recruited locally by the first author using a "snowballing" technique (Biernacki \& Waldorf, 1981) that began with the families of her own university students. All informants were back in Bali waiting for another cruise ship contract, or were waiting for their first contract. They were all male and aged from 22-40. They were well-educated. All had post-secondary diplomas, and one had a degree in English language. 11 were married and six (the younger ones) were single. In keeping with a qualitative methodology approach, these informants were interviewed "in-depth", "the in-depth interview permits the researcher to explore fully all the factors that underpin participants' answers: reasons, feelings, opinions and beliefs" (Legard, Keegan \& Ward, 2003, p. 141). From the interview transcripts we selected stories of experiences of cruise ship training and work. Although only a few of the stories collected in Bali are considered here given constraints of space, the data have been carefully analysed to show a difference between the dream and the reality of cruise ship training and work. The narratives were analysed using a thematic coding approach. This entailed reading each story carefully, while appending provisional thematic categories in note form. The process of analysis was informed by the advice of Ryan and Bernard (2000) to derive themes through rigorously inspecting, coding, and cross-checking data texts.

The narrative material from interviews with cruise ship workers in Bali was not considered sufficient, so we collected some secondary data in the forms of online commentary from a site used by young Indonesian cruise ship workers who are actually at sea. This gave a much more immediate sense of life on board. This data was subject to a content analysis to derive thematic categories similar to those gained from the narratives. Translations from Bahasa Indonesia were carried out by the first and second authors. The case study looks toward a much larger project of investigation.

\section{The Difference between Dream and Reality}

\subsection{The Actual Experience}

The dream of working on a cruise ship was found to be popular for young Balinese Indonesians in senior high school. They are drawn by the lure of international travel, income well beyond the norms for service work in local hotels, and the thrill of adventure on the high seas. However, the actual experience comes as a shock. One young man said:

\section{Pekerjaan banyak. Dituntut bekerja cepat. Tidak ada libur kecuali kontrak berakhir.}

So much work. We are required to work so fast. No time off except when the contract ends (Gus, 25, junior waiter, Royal Caribbean International).

Another young man said:

Bekerja di cruise line bagi orang awam memang menggiurkan dan menyenangkan. Tetapi realitas yang ada berbanding sebaliknya. Hidup berbulan-bulan di kapal bagai hidup di neraka.

For ordinary people, working on a cruise ship seems exciting, full of promise. But the reality is quite the opposite. Living on the ship for months is like living in hell (Agung, 28, housekeeping, Royal Caribbean International).

Living conditions for low-level service workers are overcrowded and under-resourced, with very long shift hours spent serving cantankerous and demanding guests. Cruise passengers taking the "holiday of a lifetime" (Chin, 2008) expect their needs to be met by bright, smiling young service workers, on call, who speak their language (Gibson, 2008). Although cruise ship wages seem high to young people when they are still at high school, in reality income barely covers costs for the first few years. Moreover, debts incurred in training must be repaid. The earnings of young cruise ship workers can quickly disappear, as we shall see below.

Looking at the school-to-work transition, these young people graduate from senior high school, then turn away from a university education to train for service work on cruise ships. While the youth are following an individual transition path to adulthood in one sense, their choices are not made in isolation. Traditional values of family, kin and community still prevail. Some families favor a cruise ship career, others would rather see their offspring go to university. Decision-making is best understood collectively because it is enacted not only at the level of immediate family, but also at the level of extended family. Education of younger siblings and the health care of older family members may depend on remittances. There is pressure to keep the cash flow coming once it has been established. The ambition to later start a small business back home may apply pressure to take contract after contract, at the expense of marriage and family life. These pressures can be understood as symbolic violence 
because, while it appears there are "individual choices" being made, the choices are impelled by cultural and material factors that disguise necessity as choice.

\subsection{Cruise Ship Training Colleges}

The following excerpt from an article in the Bali Post points to the proliferation of cruise ship training programs:

More than 50 graduates from LP2B [Institute for Tourism Training in Gianyar] have left to work on cruise ships. Institute director Dedek Arimbawa saw them off to Quail Cruise Lines and SS Oceanic. One graduate will work as a Spa Therapist for the MSC Cruise line (Bali Post, 2010a).

Another article in the Bali Post reported on graduation from the Balindo Paradiso training school in Denpasar, a college that works under the guidance of a direct recruitment agency owned by MSC, Bali Paradise Citra Dewata. The training was said to have "emphasized professional experience standards that matched those of the Mediterranean Shipping Cruise (MSC) line in Sorrento, Italy" (Bali Post, 2010b). Here students take courses in English, Italian, French, German, Russian and Portuguese, along with courses on sanitation and cleanliness, leadership and international etiquette. It appears that since 1999, Balindo Paradiso has produced 3467 graduates. Of these, 2255 have taken jobs on MSC cruise ships (Bali Post, 2010b).

Cruise ship recruitment literature offers young Indonesians who are still at school the dual promise of exciting travel and high wages. An online advertisement in Indonesian reads: "Attention senior high school graduates who like travelling and meeting new people. There are many opportunities to work on cruise ships that offer nine times the wages in Indonesia. Please log onto Bogor Hotel Institute". We note that the offered income is "nine times the wages in Indonesia", which must sound like riches indeed to a high school graduate. However, since the rate of "nine times" is more or less the exchange rate between the Indonesian rupiah and the US dollar, it really means the wages are low by international standards.

\subsection{From School to Cruise Ship Training}

For understanding the complexity of the school-to-work transition for cruise ship trainees, we can look at one of the personal stories collected for the case study.

Wayan is 20. His father and mother are Balinese transmigrants. They moved from Bali to settle in the eastern part of the underpopulated island of Sulawesi under the national transmigration program in the 1980s and prospered, even though they had only basic education. When Wayan finished junior secondary school (SMP) in Sulawesi, his parents decided to send him back to Bali to board with a relative in semi-rural Tabanan while he completed senior secondary school (SMA). His father's dearest wish was to see his son obtain a university degree and get a professional job, which would complete the success story of the family and raise their social status, despite the transmigrant stigma. It cost the family quite a lot of money for Wayan to get senior secondary education and live in Bali, so he did not return to Sulawesi during this time.

While at senior secondary school in Tabanan, Wayan got the idea to train to work on cruise ships instead of going to university. Cruise ship work was a popular ambition among the boys at his school because they thought it would give them travel, adventure and high wages. Wayan's parents back in Sulawesi were against the idea since they wanted him to go to university. Wayan however, was adamant. He applied to a cruise ship training college and was accepted for a one-year diploma course. It cost his parents Rp.15 million (US\$1 662) for fees and lodging. To bring his English up to the required standard he had to take an outside English course, which was also costly. By this time Wayan had not seen his family for nearly four years. As he neared the end of the cruise ship training program he went to apply for a passport, but there was a problem because he was born in Sulawesi, not Bali. Extra money had to be paid by the family in Sulawesi for Wayan to obtain an Indonesian passport in Bali.

As is common, the cruise ship training college he attended was linked to a recruitment agency. Wayan's parents had to send further funds to pay the agent so Wayan's application could be lodged and his name placed on an availability list. Wayan graduated in May 2010. At the time of writing in late 2010, months have gone by and no cruise ship contract has yet been forthcoming, even though a monthly fee is still paid to the agent. Wayan is working as a room boy in a three star hotel in Kuta on a low wage. He remains optimistic of eventually getting a cruise ship contract. His parents are in debt. They are disappointed their son did not enrol in university. If Wayan is eventually offered a contract, he will have to pay a further agent's fee, deposit his return airfare to the port of embarkation, and give half his first month's salary to the agent. His family will have to further increase their bank loan to cover these costs. 


\subsection{From Cruise Ship Training to Cruise Ship Work}

Although Wayan has yet to achieve the transition to cruise ship work, we can chart that shift by examining some postings from the online community of young Indonesian cruise ship workers. A sample of 2009 tweets from

http://blog.pelaut.biz/news/proses-recruitment-crew-kapal-pesiar-curhat-sang-pelaut ranged from advertising for cruise ship jobs, to wistful expressions of hope, to outright condemnation of cruise ship work. Although these tweets are anonymous, they do give a sense of what the young hopefuls dream of, and what life is actually like on board.

Some aspirant tweets alluded to the dream of cruise ship work, for example:

Male: I really want to work on a cruise ship. Next year I'm going to enrol.

Female: Hey hey, I want to travel around the world saving up money and getting rich working on a cruise ship.

Female: I want to get an overseas work permit you know? Cruise ship here I come!

Male: I'm working in a spaghetti house. I've heard people say that on private cruise ships in Europe, you can make 3 million rupiah (A $\$ 365.00)$ a month. Is that just wishful thinking? It makes me mad to hear it ...

Male: Guys please send me your prayers. I get my turn at a job interview for a cruise ship. Please pray for me.

The first time on board ship is a period of excitement, and spirits are still high, as the following tweets indicate:

Male: Here I am very confused and get lost because this cruise ship is so enormous. Ha ha but so what? Like I care?

Female: Usually on board a wooden raft, now I'm on board a cruise ship. Jackpot!

For some though, reality has sunk in:

Female: My feet are falling off. I'm at sea again, once again on a cruise ship. It is all bad! Sigh ...

Male: Say NO to joining a cruise ship crew ...

Male: It's morning and I've just knocked off work you know? I wish I was a cruise ship passenger heading home ... But I'm a DJ dishwasher jockey ...

Male: Regarding work schedules for general staff apprentices on cruise ships, they're totally shit. Horse shit/cow shit. Don't you agree?

Male: I'm very tired here today. My section is full of Europeans: stupid, lazy and arrogant. I might add that their dinner menu is far away from the word enjoyable ... so they're emotional right now ... "Hey we made personal sacrifices to travel on this boat" ... and so on.

\subsection{In the job}

As the interview quotes in 4.1 and the tweets in section 4.4 imply, the reality of cruise ship work simply does not match the dream. The following story of Nengah, an older worker, demonstrates the struggle that younger aspirants will face in their quest to build up capital:

Nengah, 37, is now on his third cruise working in the kitchen. He applied initially through the Denpasar agent Bali Paradiso after seeing a newspaper advertisement. He had ten years experience as a hotel cook in Lovina and wanted a higher income. First he purchased an application form for Rp.100 000 (US\$11). Two weeks later he gained an interview. He was assessed on greetings and simple conversation in English. He was also asked to give greetings in Italian and French. Nengah was offered a 9 month contract. He had to pay Rp.32 million (US\$3 547) for a 14 day training program in Surabaya. He spent another Rp.10 million for travel to Surabaya, accommodation, food, passport, visa and so on. All the pre-departure money was borrowed from a bank. Nengah was paid US\$1 001 per month. 50 per cent of his salary for the first month was paid to the agent.

When Nengah came home, the bank debt had to be settled, so he was left with just a few hundred US dollars. Fortunately his wife has a job. Nengah quickly signed a second contract from July 2009 until April 2010. This time he had to pay the agent Rp.12 million (US\$1 330), which required another bank loan. Once again the agent was paid 50 per cent of the first month's salary. This time when he returned, Nengah had a few thousand US dollars left after repaying the bank debt. He invested the money in his wife's education. She is taking a Masters degree in the hope of getting a job as a public servant. In October 2010, Nengah left for a third voyage until July 
2011. This time he only had to pay Rp.8 million (US\$886) for the agent's fee, and 50 per cent of the first month's salary. He anticipates that he will have saved enough money by July 2011 to buy a used car. Nengah's wife finds the time apart very difficult. She misses her husband, money is short and her mother looks after their small daughter while she works and studies. Nengah's long term goal is to start a small agribusiness. However, he is not confident he will get a fourth contract because of his age. There are now many younger applicants such as Wayan - who have completed more prestigious training courses.

\subsection{What Happens After Cruise Ship Work?}

Southeast Asian cruise ship workers normally retire from cruise work between the ages of 30 and 35 . No longer fresh-faced and energetic, they are not as attractive to cruise ship agents as younger workers. Few reach the managerial level, because cruise ship employers prefer European staff to manage.

Some tweets referred to life after cruise work, for example,

Male: Married now so I've thrown out the anchor. Even though a thousand shining cruise ships are calling to me, I like it here.

Male: Although cruise ship work builds up money, when you get back to the village you are still poor, basically going backwards.

Two personal narratives from Singaraja further demonstrate the fractured nature of family life, and what happens after cruise ship work is given up:

Komang is now 32. At the age of 21 he managed to get a cruise ship contract even though he did not complete a specific program. He got the contract through family connections (social capital) following completion of an ordinary three year Diploma in Tourism (D3) at the local university. His family paid far, far less than Wayan's parents, although this was 10 years ago. Just before he left for his first cruise ship job in the Mediterranean, Komang got married to a local girl. When he came back 8 months later, his wife gave birth to a baby. He stayed in Bali for a year, living on his savings and picking up some casual work. Then he departed for another contract. When he came home, his wife gave birth again. Four children were born in this pattern. Komang has just given up cruise ship work to open a local "family" karaoke restaurant with his savings.

Ketut is now 38. He came into cruise ship work not through a college diploma, but through recognition of prior experience in tourist hotel kitchens. He took contracts on cruise ships for more than 10 years, working his way up to the position of kitchen supervisor earning US\$1 010 per month. He stopped taking cruise ship contracts because his children were getting older and he wanted to spend more time with them. Using his cruise ship experience and savings, he opened a small restaurant in Sanur. Ketut said that on the cruise ships he worked 8-12 hours every day. There was nothing he liked about the work except being able to explore different ports with some of his co-workers when he got a half-day shore leave.

\section{Discussion}

\subsection{Dreams and Disappointment}

The data presented in 4.0 above point to the gap between the dream and the reality of cruise ship work. As the aspirant tweets in section 4.4 reveal, cruise ship work is viewed idealistically by young Indonesians. Material benefits are uppermost. One girl believes she will get rich. Another was sure that cruise ship work would lead to an overseas work permit. The lad working in a spaghetti house can barely believe the promised wage for cruise ship and it makes him "mad" - probably with longing - imagining how he could live in Indonesia on such an income. The story of Wayan in section 4.3 shows how strong the dream was for him, since he went against the wishes of his family for a university education. However, despite the large amounts of money paid by his family, the dream has not materialized for him. He earns just enough to keep himself in his current job. In the case of both Wayan and the aspirant tweets, we can see how young people "talk up" the dream of cruise ship work amongst themselves. It seems someone always knows someone who has earned a great deal of money from cruise ship work and bought a house, a car, and started a business back home. In short, the dream of upward social mobility at home drives the ambition to temporarily migrate for cruise ship work. This is far from uncommon in Southeast Asia, and there is always a gap between the dream and the reality. Moreover, repaying debt always compromises the capacity to create savings. However, the usual forms of temporary migration for work do not normally involve such a large outlay of money for initial training as Wayan's parents were compelled to provide, only to find no promised contract. Nor do so many well-educated young Balinese with other career options actively seek out the more common forms of temporary overseas work, because the regional trade in manufacturing, building labor and domestic service jobs is associated with lower class people. Cruise 
ship work as a form of temporary work migration has some unique status characteristics that need to be identified in terms of international class relations, and the construction of the self as a privileged worker.

\subsection{Cruise Ship Work and Symbolic Violence}

As we saw above, tweets from new recruits in section 4.4 reveal their good-humored initial adjustments to life on the cruise ship. However, it may be assumed that working so hard for an income far less than anticipated palls after a while. The problems mentioned in sections 4.4 and 4.5 by more seasoned workers: inability to save, fatigue, sore feet, long shifts, exhausting schedules and unhappy, demanding passengers; contradict both the rhetoric of cruise ship recruitment advertising, and the excited anticipation of senior high school students. As stated in section 2.1, the cruise ship employment sector is under-regulated, and conditions for workers on many ships are challenging. After more than ten years of working on cruise ships, Ketut could remember only one thing he liked about the work, and that was time off in port. On the other hand, after ten years he had saved sufficient money and gained sufficient experience to open a small restaurant in the upmarket tourist area of Sanur. This ambivalence returns us to Bourdieu's argument about the nature of symbolic violence in section 1.2. Symbolic violence is an exercise of power upon the social actor with his or her complicity, a kind of mundane suffering that "defies the ordinary alternative between freedom and constraint" (Bourdieu 1982, p. 36). The local push and pull factors described in section 1.4 create a set of circumstances for the choosing social actor that facilitates the intervention of recruitment agents working for international cruise lines, and the encouragement of family members aiming for prosperity. For example, given high local graduate unemployment, an ambitious senior high school student today who heard Ketut's story in Singaraja would be more inspired by the fact that he opened a restaurant than dissuaded by the confession that he disliked the job so much. In other words, pursuing a career in cruise ship work entails complicity with exploitative labor conditions by assuming the long-term benefits will outweigh the suffering.

As one of the tweets in section 4.4 revealed, it is not only young service workers who might find the cruise experience disappointing. The operation of symbolic violence is not just confined to the crew. Passengers were dissatisfied with their meals and the young service staff bore the brunt of complaints. There is some support for the bad food claim. Starmer-Smith (2010) reports that the annual Berlitz Complete Guide to Cruising and Cruise Ships lists Royal Caribbean International as the worst of the world's major cruise lines for service and cuisine. Carnival Cruises and Costa Cruises fared little better on the Berlitz ratings. The cuts of meat and range of wine were second rate and there was a lack of green vegetables and fresh fruit. As the guide states, this is because mass cruising lines spend as little as possible on ordinary passenger food costs, just as they do on low-level staff wages, because the aim is profit. To better understand the complex nature of the operation of symbolic violence for both passengers and young service workers, we need to recall the visual impression of breathtaking luxury that cruise ships convey. The representation of opulence and high living derives firstly from the sheer size of the vessel, secondly from the fittings and interior decoration, and thirdly from the provision of restaurants, shops, swimming pools, gyms, cinemas, spas, beauty salons, casinos and so on. Enthusiastically boarding a cruise ship for the first time, the social actor is compelled to feel a sense of privilege, of engaging with extraordinary luxury: - the "holiday of a lifetime", the "dream job". Yet for both the passenger and the cruise ship worker, he or she has signed up for a fixed period on board, and is constrained to remain even when the actual experience does not live up to expectations.

A form of symbolic violence happens for the crewmember. The young well-educated worker is compelled to adjust his or her middle class habitus to that of a colonial servant. But in the "total institution" of the cruise ship this may seem quite natural. As Bourdieu stated, "symbolic domination... is something you absorb like air, something you don't feel pressured by; it is everywhere and nowhere, and to escape from that is very difficult" (Bourdieu 1992, p. 115). In "choosing" cruise ship work the young Indonesians embark on a journey they envision will lead to material and social improvements, that is, they are complicit. Nevertheless, symbolic violence is experienced in the suffering that results from the disjuncture between the myth and reality of cruise ship work, and between the actual and the ascribed class position of the young workers.

\subsection{Perpetuating the Myth}

In terms of class, the tweet by a new young female worker in section 4.4 on her upward mobility from a wooden raft to a cruise ship is worthy of deeper consideration. Even middle-class Indonesians will sometimes travel on flat wooden rafts or flat boats to go to school or work each day if it is the quickest way to cross a river or waterway. This would certainly be a very unusual means of daily transport in the developed world. The writer implies that the contrast between her wooden raft experience at home and the giant luxury cruise ship that is now her place of work means she has won the jackpot - in class terms perhaps. However, it could be argued that she 
feels she has achieved upward class mobility simply because the cruise vessel seems so luxurious, while really, she has gone from middle class status in Indonesia to servant status on board ship. As a perception it is similar to the advertised promise in section 4.2 that cruise ship income will be nine times what could be earned at home, when this simply reflects the exchange rate between the rupiah and the US dollar. Perceptions of wealth and luxury have something important to tell us about the imagined self of young people in the cruise ship work experience. Believing from appearances and rhetoric that they have entered a realm of wealth and privilege (apparent upward class mobility), they willingly modify their habitus to match the demeanor of the compliant colonial servant, and accept harsh working conditions (symbolizing downward class mobility). Furthermore, they hope to gain upward class mobility at home, but neither the income nor the eventual savings are what they expected, as the example of Nengah in section 4.5 illustrates. This is another expression of the symbolic violence that operates in cruise ship work. Nevertheless, the post-career success of being able to set up a business with saved money encourages the myth and perpetuates the dream. Rarely was there any reference in accounts from informants of the fact that cruise ship work disrupts family formation and family life. Although they are still a minority, young women who take up cruise ship work are particularly likely to be negatively affected. They run the risk of never marrying, which in Indonesia means never fully attaining adult status. This certainly would be a case of postponed, if not arrested adulthood.

\section{Conclusion}

\subsection{International Class Relations and the Cosmopolitan Worker}

Preliminary project data represented here indicate that cruise ship work is a post-school career choice with far-reaching consequences for young Indonesians, their lives and their families. The difference between service work in the local tourism industry, and cruise ship work, was demonstrated with reference to long periods spent at sea in the "total environment" of the massive transnational cruise liner where labor regulations do not apply as they do elsewhere. The wealth dreamed of in high school proves hard to attain, yet there is pressure to keep accepting contracts to pay debts and have something to show at the end of career.

We conclude that the transnational cruise ship industry is not only a microcosm of the globalized labor force, with young Southeast Asians working at the lowest status level, but represents a new form of international class relations constructed around western consumer culture. In terms of the self, service work carried out in the total environment of the cruise ship demands the cultivation of an especially subservient demeanor on the part of young worker who may, paradoxically, occupy a relatively privileged middle-class position at home. The reality does not match the dream when it comes to either income or the excitement of international travel. In the case of Wayan, neither has materialized so far, but his parents are certainly out of pocket. For Nengah, his sacrifices may all be in vain if he fails to gain another contract because he is too old compared to the new crop of specially trained young applicants like Wayan. In summary, we find new forms of symbolic violence in the complex pattern of temporary migration for cruise ship work by young Southeast Asians as they move toward adulthood. The reader might be concerned that our focus on symbolic violence demeans those Indonesian crewmembers who experience "real" violence such as beatings and assault. But such abuse seem to be rare compared to more subtle forms of exploitation and humiliation such as those discussed above. Dismissing the legitimacy of suffering under symbolic violence is an act of symbolic violence in itself. "Denial in effect blames the victim" (Schubert, 2008, p. 195).

The well-educated flexible young worker of the new millennium is often claimed to be more cosmopolitan than previous generations. However, the laudatory term "cosmopolitan" needs to be cautiously applied to young service workers on international cruise liners sailing under flags of convenience. Young Indonesian cruise service workers may be located in a cosmopolitan work space, but they do not experience acculturation to a new country or free engagement with the "other" - the passengers. Instead they labor in a geographically isolated total environment of 24 hour service work subject to few international regulations. Here they come to rely intensely on each other to maintain local identity and pride. We hope to explore this peer solidarity in future research on cruise ship work and young people.

\section{References}

Anderson, P. (2007). Russia's managed democracy. London Review of Books, 29(2), 6-12.

Bali Post. (2010a, July 23). Tourism training graduates from Gianyar leave for work on cruise ships. [Online] Available: http://www.bps.go.id (4 December, 2010).

Bali Post. (2010b, April 1). Cruise ship work opportunities still widely available. [Online] Available: http://www.bps.go.id (4 December, 2010). 
Beck, U. (2002). The cosmopolitan society and its enemies. Theory, Culture \& Society, 19(1-2), 17-44.

Biernacki, P., \& Waldorf, D. (1981). Snowball sampling. Sociological Methods Research, 10, 141-63.

Bourdieu, P. (1982). Ce que parler veut dire. L'économie des échanges linguistiques. Paris: Arthèmes Fayard.

Bourdieu, P. (1987). What makes a social class? On the theoretical and practical existence of groups. Berkeley Journal of Sociology, 32, 1-17.

Bourdieu, P. (with Eagleton, T.) (1992). In conversation: doxa and common life. New Left Review, 191, 111-121.

Calhoun, C. (2002). The class consciousness of frequent travellers. In S. Vertovec \& R. Cohen (Eds.), Conceiving cosmopolitanism - theory, context, practice (pp. 89-110). Oxford: Oxford University Press.

Chin, C. (2008). Cruising in the global economy: profits, pleasure and work at sea. Aldershot: Ashgate.

Cieslik, M., \& Pollock, G. (2002). Introduction: studying young people in late modernity. In M. Cieslik \& G. Pollock (Eds.), Young people in risk society (pp. 1-21). Aldershot: Ashgate.

Côté, J. (2000). Arrested adulthood. New York: New York University Press.

Côté, J. (2003). Late modernity, individualization and identity capital: some longitudinal findings with a middle-class sample. In Making braking borders $7^{\text {th }}$ nordic youth research symposium, 7-10 June 2000 Helsinki, Finland. [Online] Available: www.alli.fi/nyri/nyris/nyris7/papers/cote.html (10 April, 2005).

Cruiseshipjobs. (2010). Life on board \& Tips from a recruiter. [Online] Available: http://www.cruiselinesjobs.com (2 December, 2010).

Fokwang, J. (2008). Youth subjectivities and associational life in Cameroon. Africa Development, 33(3), $157-162$.

Furlong, A. \& Cartmel, F. (2006). Young people and social change: individualization and risk in late modernity. (2nd ed.). London: Milton Keynes/Open University Press.

Gibson, P. (2008). Cruising in the $21^{\text {st }}$ century: who works while others play? International Journal of Hospitality Management, 27(1), 42-52.

Goffman, E. (1961). Asylums. New York: Doubleday.

Jardine, D. (2008). Indonesia: High graduate unemployment. University World News. [Online] Available: http://www.universityworldnews.com (7 November).

Legard, R., Keegan, J., \& Ward, K. (2003). In-depth interviews. In J. Ritchie and J. Lewis (Eds.), Qualitative research practice, pp.138-69. London: Sage.

MSC Cruises. (2010). Our ships. [Online] Available: http://www.msccruises.com/gl_en/homepage.aspx (2 December, 2010).

Nilan, P. (2008). Youth transitions to urban, middle-class marriage in Indonesia: faith, family and finances. Journal of Youth Studies, 11(1), 65-82.

Ritzer, G. (1999). Enchanting a disenchanting world: revolutionizing the means of consumption. Thousand Oaks, CA: Pine Forge Press.

Roberts, K., Pollock, G., Rustamova, S., Mammadova, Z. \& Tholend, J. (2009). Young adults' family and housing life-stage transitions during post-communist transition in the South Caucasus. Journal of Youth Studies, 12(2), 151-166.

Ryan, G., \& Bernard, H. (2000). Data management and analysis methods. In N. Denzin \& Y. Lincoln (Eds.), Handbook of qualitative research. Sage. London.

Schubert, D. (2008). Suffering/symbolic violence. In M. Grenfell (Ed.), Pierre Bourdieu: key concepts, pp. 183-198. Acumen: Stocksfield.

Seal, K. (1998, March 2). Cruise ships draw new crews. Hotel \& Motel Management Magazine, 9.

Skelton, T. (2002). Research on youth transitions: some critical interventions. In M. Cieslik \& G. Pollock (Eds.), Young people in risk society, (pp. 100-116). Aldershot: Ashgate.

Starmer-Smith, C. (2010, 18 October). World's worst cruise line for food and service named. Sydney Morning Herald. [Online]

Available: http://www.smh.com.au/travel/travel-news/worlds-worst-cruise-line-for-food-and-service-named-20101018-16pr m.html?comments=26 (2 December, 2010). 
Sziraczki, G. \& Reerink, A. (2004). Report of survey on the school-to-work transition in Indonesia. GENPROM working paper no. 14. Geneva: International Labour Office.

Threadgold, S. \& Nilan, P. (2009). Reflexivity of contemporary youth, risk and cultural capital. Current Sociology, 57(1), 47-68.

Threadgold, Steven. (2011). Should I Pitch my Tent in the Middle Ground? On 'Middling Tendency', Beck and Inequality in Youth Sociology. Journal of Youth Studies, Vol. 14, No. 4, June, 381-393.

UNDP. (2008). Human development report 2007/2008. Washington: United Nations Development Program.

Weaver, A. (2005). Interactive service work and performative metaphors: the case of the cruise ship industry. Tourist Studies, 5(1), 5-27.

White, B. (2007). In search of middle Indonesia. [Online] Available: http://www.kitlv.nl (17 September, 2009).

Wilkinson, P. F. (1999). Caribbean cruise tourism: Delusion? Illusion? Tourism Geographies, 1(3), 261-282.

Wood, R. E. (2000). Caribbean cruise tourism: globalization at sea. Annals of Tourism Research, 27(2), 345-370.

Wood, R. E. (2002). Caribbean of the East? Global interconnections and the Southeast Asian cruise industry. Asian Journal of Social Science, 30(2), 420-440. 